\title{
GEOLOGICAL MAGAZINE
}

VOLUME LXI.

\section{No. XII.-DECEMBER, 1924. \\ EDITORIAL NOTES.}

THE news of the death of Sir Archibald Geikie on 10th November will have been received with profound regret by geologists throughout the world. He long ago established his claim to the leadership of our science in this country left vacant by the death of Sir Charles Lyell in 1875, and he has been universally recognized both at home and abroad as the foremost British geologist. It was once aptly said that on him had "fallen the mantle of Lyell, a mantle in which the warp of science and the weft of literature are so deftly interwoven". His luminous writings and vivid personality have undoubtedly added greatly to the esteem in which geology is now held by devotees of the other sciences and by the general public. The saying "nihil tetigit quod non ornavit" is indeed specially applicable to him.

A brief sketch of Sir Archibald's life and work up to 1890 will be found in the Geologrcal Macazme for that year, as one of the series of "Eminent Living Geologists". For the later period reference may be made to his autobiography "A Long Life's Work", reviewed last month. Another biography is obviously unnecessary but it is hoped to publish in an early number an appreciation of his influence on the geological work and thought of his time.

Since the foundation of the Geological Society Club in 1824, members have dined together on the occasion of every ordinary meeting of the Society.

5th November, the date of the last meeting, was the centenary anniversary of the first Club dinner, and on this special occasion over a hundred guests, including distinguished representatives of kindred clubs, were invited to join the members at dinner.

The President, Dr. J. W. Evans, F.R.S., occupied the chair.

Sir W. Boyd Dawkins, proposing the toast of the kindred clubs, referred himself to "the pre-historic period " in the Club's history; for he was a member in $\mathbf{1 8 7 4}$, when the Club celebrated its jubilee. In reminiscent mood, he described those old-time dinners as occasions when, by tacit agreement, the robust controversialists of the period observed at least a temporary truce.

vol. LXX.-NO. XII. 
In replying to the toast, Sir Charles Sherrington, President of the Royal Society, remarked that the latter could with some justice claim the Geological Society as a daughter society. He read out a choice selection of amusing light verse perpetrated by the oldtime diners which he had found in a manuscript book of the Rev. Professor Thomas Wiltshire, a former Treasurer. Not all these poetic efforts had a direct bearing on geology.

Sir A. Smith Woodward next proposed the guests, and to this toast Sir Richard Gregory and Professor Schaffer, of Vienna, replied. Sir Richard never spoke in happier terms. Professor Schaffer remarked that the century of scientific comradeship and geological achievement which the occasion marked appealed to his imagination more than anything else in the geological past, and that the antiquity of the Club's snuff-box claimed his profound respect.

To the toast of the Geological Club, proposed by Sir William Bragg, the President replied by reminding those present of the great advances made in geological science since the Club was founded. A century ago, the four oldest Palaeozoic periods were unrecognized; Lyell, who was a founder of the Club, and survived to take part in its jubilee, had not subdivided the Tertiary ; the Glacial period had not been established, nor had pre-historic man been discovered or the theory of evolution been formulated. Moreover, thin rocksections and the petrological microscope were alike unknown.

Dr. Evans concluded his remarks by an appreciative reference to the responsibilities of the Club treasurer, and sketched his impressions of several holders of that office in the past. He proposed the toast of the past treasurers and more especially of the present treasurer, Mr. G. W. Lamplugh, to whom he paid a warm tribute.

Mr. Lamplugh, in reply, expressed his sense of indebtedness to his predecessor in the post, Professor W. W. Watts, whose sound policy he was content to continue during his own term of office. He pointed out the curious coincidence that at both the Jubilee and the Centenary dinners a John Evans presided.

Letters of greeting, signed by those present at the dinner, were forwarded to four honorary members who were unable to be present : Sir Archibald Geikie (whose death occurred on 10th November), Mr. William Whittaker, the Rev. Canon Edwin Hill, and Mr. E. T. Newton.

To each member and guest was presented a souvenir booklet giving the history of the Club, and a list of members during the century of its existence. 